\title{
Inculturation of Protestantism in Vietnam: Philosophical Aspect
}

\author{
Mai K Da \\ Department of the History of Philosophy \\ Peoples' Friendship University of Russia \\ 6 Miklukho-Maklaya Str. \\ Moscow, Russia \\ E-mail:maikda@mail.ru
}

\begin{abstract}
Inculturation" is an important concept of Christian theology. It was a central theme of Christian theology in Asia in the late XX century - beginning of XXI century and it is also an essential matter of philosophical reflection and Protestant theology in Vietnam in the modern period. Analyzing the basic aspects of this concept, the author of this article wants to initially analyze the inculturation efforts of Protestantism in Vietnam when facing strict conflict with native culture during evangelization process.
\end{abstract}

Keywords-inculturation; Protestantism in Vietnam; Christian theology; religions; theology of culture; contextual theology

\section{INTRODUCTION}

Inculturation is considered to be central point of Vietnamese Protestantism theology meditation in modern period. This issue has been arisen in actual evangelization process of Protestantism over a century since its arrival in Vietnam. With the rigid evangelization method and point of non-recognition Vietnamese cult of ancestors, Protestantism had aggravated distrust of local natives. Until now, Protestantism has been known as a "strange" religion, "outside standing" religion with Vietnamese culture [1]. In such context, the necessarry mision is constructing a philosophical basis for Vietnamese Protestantism theology. Theology not only tends to contribute to the construction of Church by clarifying entanglement and deepening in faith knowledge, but also resolve relationship matter between religion and Vietnamese culture toward purpose of reconciliation and unculturation with native culture.

\section{INCULTURATION: PHILOSOPHICAL ANALYSIS}

The term "inculturation" is commonly used in Christianity. This term is initially used in 1962 by Doctor Fr. Josehp Masson S.J of Gregory University in Roma in years before the Second Vatican Council in 1962. He mentioned that the problem of integration is the dialogue between the gospel and culture, more precisely, that is finding appropriate ways to integrate Christian faith into local culture. Therefore, when Christian faith appears in culture, dialogue must occur. And this is a process without ending because faith cannot exist outside culture [2]
The debate on the relation between the Gospel and cultures had given a new theological point of evangelization as "inculturation". There are many different points of this term. We need to clarify some concept related to inculturation such as: ac-culturation, en-culturation.

"En-culturation" (or "enculturation" or "endoculturation") is the process by which an individual engages himself in the culture of his/ her original social group [3]. Culture shall be learned but not natural. It is not a process of absorbing culture passively, but a conscious absorbing process. For Christians, they share a common culture with other members of the church.

Ac-culturation is the dynamic process of a culture when encountering another culture. The two cultures influence each other. This reaction brings different effects for each culture, possibly borrowing, imitating one another, possibly leading to new developments or syntheses. Ac-culturation is a direct consequence of the dynamism and extension of all cultures. When the Gospel is preached in a place in which its culture is available, evangelization process always produces ac-culturation in which the Gospel, the preacher's culture, and the culture of the listeners shall be harmonious. The essence of local culture must exist, but it must be transcended by the Gospel and become more human through contactting with aother human culture [4]

Inculturation is a new term. For Christianity, this term is seen as value for expressing the relationship between the gospel and cultures. It is not any anthropological or sociological term. Although inculturation is related to anthropology, inculturation is a theological term because inculturation is a direct consequence of the inner movements of the cultural and faith which is wanted to be osmotic to culture. Moreover, inculturation is the transformation of a culture through the gospel and application of the gospel to culture.

In order for an authentic inculturation, there must be a sincere continous dialogue between the Christian faith and the culture of receiving this faith. The inculturation process does not begin from evangelists, but from receivers who respond to faith. In other words, the subject of inculturation is recievers of the faith. They are who had introduced 
elements changed by faith into their culture. They also have created necessary change to accept this faith.

Inculturation requires an in-depth study of the cultures of the nations where the gospel is introduced in order to share all their values. Therefore, inculturation does not deplete all of its capabilities in the relationship between the two cultures - the original culture of evangelizers and the culture of recievers. In this sense, inculturation is a reciprocal process between the gospel and culture, which can be understood as "the incarnation of the Gospel into native culture and bringing these cultures into the life of the Church."

The mision of finding "Asian identity" of Christian theology or the desire to build a theology of inculturation had been set up by theologians in Asia. It became a major topic, leading concern of theology in Asia in the late XX century beginning of XXI century. According to Asian theologians, inculturation - "embodiment" Christian into a culture is considered as "a compicated process because the gospel of Christain has been is reflected, expressed and existed in a culture in which Christianity has not made much of its incarnation. It is duty of local churches to seek expression method of their identity through symbols belonging to their own native culture [5]. The purpose of this duty is to make church become a part of local life. Thus, Asian theologians asserted that inculturation is not a rigid reception, but a creative reception of faith into the local church. It is a twoway process, both Asia and Christian gospel are purified and transformed.

However, inculturation is a complicated matter in Asia. One of the reasons of this matter is that inculturation must bring Christain faith into a multi-racial, multi-religious and multicultural area; but this faith must hold its allegiance to the Bible. According to M.Amaladoss, inculturation will not occur if Christian is still in strange position to culture that Christian accesses. Inculturation requires that the Christian must engage and integrate into history and culture of the natives in a sincere way [6]. According to Choan Seng Song, bringing theology into Asian cultures, instead of following the theological topics and conclusions that was developed outside of Asia, it is necessary to respect the findings of Asian researchers. Chritain theology mus be a party of culture, it can not be outside, isolated, detached from culture. There will not exist Asian theology if we do not thoroughly understand the grammar, explain the syntax and research deeply into the meaning of Asian culture [7]. Pastor A. Pieris argued that inculturation must get involved in culture rather than participate in a prior intended action plan.

Therefore, it is difficult to achieve inculturation without changing the point of "Christain is transcended in every culture" and "Asian cultures are not ready to accept the gospel." From the experience of evangelization, Asian theologians tend to build a theology of inculturation in the multicultural and multi-religion context of Asia.

\section{INCULTURATION OF PROTESTANTISM IN VIETNAM}

Like Catholicism, when Protestantism was introduced into Vietnam, int confronted with the great challenge of inculturation (making Christian faith deeply rooted in local culture to make it not be considered as alien), challenge of liberation of the poor (most of Asia's people were in poverty), dialogue with other religions (there were many great religions in Asia). In Asia and Vietnam, general missions of Christanity theology is finding, reading, express the bible or explaining Christian faith in accordance with the scio-cutural context, religion, psychology, lifestyle of local natives. Purpose of such mission is to make Christian faith pervasive into to Asian's lives. This is also a special concern of Protestant in Vietnam.

In this context, Protestantism in Vietnam can follow medications of Contextual theology nominated by Asian Protestantism in 1987, which emphasized the matters of religion and ideology; migration and land; environment and technological revolution; social classess especially women, chidren, labor, etc. Protestantism in Vietnam can refer to model of Christopher Durai Signh (India) with 04 harmnious elements: Asian sensation, localization, contextualization, and concretization.

Recently, thoelogy of culture of famous theologians such as Paul Tillich (1886-1965), H.R. Niebuhr (1894-1962) has been researched seriously by Protestanity researchers in Vietnam. Besides analyzing the relationship between Christ and the depth of culture, these theologians also paid attention to its relationship with local culture.

Regarding to relationship between Christianity and culture, it is impossible not to mention "Christ and Culture" Richard Niebuhr theologian [8]. He mentioned 5 theses for this issue: 1) Christ and culture in paradox, 2) Christ against culture, 3) Christ of culture, 4/ Christ above culture, 5/ Christ the transformer of culture [9].

In "Christ and culture in paradox", the fundamental harmony between Christ and culture is confirmed. Christ is considered a part of culture, a perfect cultural model, the synthesis of all human aspirations.

In "Christ against culture", the opposition between Christ and culture is emphasized. According to the author, Christ or Christian faith is considered to be confict with the customs of the society in which the Christian is living. Therefore, culture is known as bad thing and Christian do not follow absolutely. This thesis directed Protestantism missionaries in early mission period in Vietnam that they came up with very strict regulations: followers must give up traditional culture and local beliefs.

In "Christ of culture", Christ is identical with God but is also a part of culture. Theoretically, there is no conflict between culture and Christian truth. Actually, culture is needed to change.

"Christ above culture" point expresses the disruption of human culture, and in such disruption (or when having disruption) a conflict between God and mankind will appear. Christian is considered as resident of both two countries which are in confict. Christ is considered to be a judge of culture. The view of "Christ the transformer of culture" holds that human culture is good at first, but then fails. Therefore, it is necessary to transform all aspects of human culture. The 
Christian should work to transform culture to the glory of God.

Richard Niebuhr argued that each of above theses contains truth and none of them is perfect. They are mutually supportive. Christian do not avoid community but action to change culture and social. These standpoints of Richard Niebuhr have been absorbed and analyzed quite well by many researchers in Vietnam.

In "Theology of Culture", Theologian Paul Tillich paid attention to the relationship between theology and culture or the relationship between the Christian and the profan world. According to the author, Protestantism had a specified "Theology of Culture". In which, "Culture is in essence a religion, and religion is in the expression of culture" was emphasized as a important point. Based on theology of culture, Paul Tillich mentioned the contacting methods between Christ and profan culture.

For Protestantism in Vietnam, the typical representative of inculturation trend was Pastor Le Hoang Phu. In his doctor's thesis, threes principles in constructing Autonomous Church is self-support, self-government and self-propagation; he also developed 2 more principles: self-nature and selfexpression. According to Le Hoang Phu, "self-nature" and "self-expression" principles is not only related to constructing local church but also effected to the most necessary matter of Protestantism in Vietnam, which is: attitude of Protestantism to local culture.

"Self-expression" means that faith can be expressed through literature, ritual, art from native tradition. He emphasized that a church is considered to be indigenous when "self-nature" and "self-expression" principles can be described with a philosophy through local culture. If this is achieved, Protestantism can make itself be an integral part of national culture, and also contribute value to the heritage of universal Christianity in the world. "This point of Le Hoang Phu is profound and important for launching inculteration of Christianity in Vietnam [10].

In "The gospel and culture", the author Le Van Thien analyzed philosophical points on relationship between Christ and Culture of Richard Niebuhr deeply. In this work, he emphasized the importance of inculturation and stated that "inculturation shall express the gospel as a result from human demand of religion, social, economy and cultural politics; on the other hand, inculturation shall make the gospel become osmotic into and gradually change each aspects of culture" [11]. The unique point in his view is that he emphasized that Protestantism should have a thorough understanding of the National cultural identity so as to easily integrate the gospel into the mind of the people. Bringing the gospel to the Vietnamese people by understanding and appreciating aspects of Vietnamese culture, or in other words, using cultural identitty to connect the gospel with the listener in context is considered to be important key of inculturation of Protestantism in Vietnam.

According to Le Van Thien, inculturation is Contextual theology. Pastor Huynh Thien Buu followd the path of Le Van Thien. When analyzing the collisions of Protestantism with Vietnamese culture, he believed that cultural collisions is inevitable in the process of religion mission but there are collisions that can be avoided like proscribing national musical instruments, disregard the local daily customs. He also bluntly criticized that Protestantism in Vietnam had issued "too strict requirements, following Western method" [12]. Therefore, the author introduced methods, tools, ways of religion mission in direction of "Inculturation". He believed that inculturation can start with using of national music (instruments, dance) in church worship and activities. His point had gained a certain amount of attention in the Vietnamese Protestant cominity.

Pastor Truong Van Thien Tu wanted to find the "Inculturation" of Protestantism in Vietnam by analyzing the most fundamental theological issues in relation to the cultural depth of the Vietnamese people. In his doctor thesis named "Heavenly mandate - Towards a theology of Vietnamese mission" in Berkeley, California, he criticized mistakes in inculturation of Protestantism in Vietnam and emphasized the necessary to participate in society of Vietnamese Evangelical Church.

Thus, Protestantism had made certain efforts in finding ways of inculturation of this religion in Vietnam. This is an urgent misson and effected to its success in spreading the faith. Inculturation is also in line with the historical reality of religions in Vietnam, where no religion can be rooted in the national life without change to fit the context of Vietnamese people

\section{CONCLUSION}

Protestantism was introduced in Vietnam when Vietnamese culture was under influence of the Three Religions - a longstanding religion in Vietnam for centuries. Strict confilct with native cultures propelled the gospel become an "outside" religion to national culture. In such context, the mission of finding and construction a theology that Christaint theology shall have inculturation into Vietnamese culture was posed and received much attention from researchers. The points of Richard Niebuhr, Paul Tillich on the relationship between religion and culture, as well as the movement of Asian theology are considered as the source of ideas for the gospel in Vietnam looking for a path. Le Hoang Phu's point of building a self-reliance church, the theological context point of Le Van Thien, and many other researchers' thoughts initially shaped the development of Vietnamese theology in modern period.

\section{REFERENCES}

[1] Do Quang Hung, Theological issues of Protestantism in Vietnam today. Hanoi: Journal of Vietnamese social science, No. 6, 2011, p. 110.

[2] Le Van Thien, The gospel and culture. Hanoi: Ton giao Publisher, 2010, p. 107

[3] Aylward Shorter, Toward a Theology of Inculturation. New York: Orbis Books, 1988, p. 5.

[4] J. Friede, Vida y luchas de D. Juan del Valle, primer obispo de Popayan y protector de indios. Popayan: Popayan Publisher, 1961, p. 31. 
[5] Nguyen Phu Loi, Aspects of Asian Theology (part 2). Hanoi: Journal of religious studies, No. 5, 2006, p. 18.

[6] M. Amaladoss, Beyond Inculturation, Can the Many Be One? (Translated to Vietnamese by Le Cong Duc). Delhi: Delhi Vidyajyoti Education \& Welfare Society, 2005, p. 30.

[7] Choan Seng Song. "Theology in the Asian way". Ho Chi Minh" Catholic Solidarity Committee in Ho Chi Minh City, 1991, p. 18.

[8] S. A. Nizhnikov, The spiritual problem in Western and Eastern culture and philosophy. Moscow: INFRA-M, 2012, p.63.

[9] Christ and culture: five views. [Electronic resource]. URL: https://www.focusonthefamily.ca/content/christ-and-culture-fiveviews.

[10] Le Hoang Phu. History of Evangelical Church of Vietnam (19111965). Hanoi: Ton giao Publisher, 2010, p. 392.

[11] Le Van Thien, The gospel and culture. Hanoi: Ton giao Publisher, 2010, p. 128.

[12] Huynh Thien Buu, Essay on Church service. Five-year mission plan of Evangelical Church of Vietnam (South Vietnam) 2005-2010. Ho Chi Minh: Institute of Vietnamese Theology, 2004, pp. 4-5. 